\title{
The 'Turn' to Time and the Miscarriage of Being
}

\author{
Virgilio Aquino Rivas
}

\section{Groundwork}

$\mathrm{M}$

artin Heidegger and Immanuel Kant-two important pillars of contemporary philosophy-were proficient critics of traditional metaphysics in their time. They were known to be critical of a sort of metaphysical striving predisposed to grounding or representing an elusive concept of the universal. (At least, for Kant, the limits of representation are problematized vis-à-vis the regulative principle of the mind). Kant had earlier deconstructed a pre-eminent feature of Western metaphysics, namely, the socalled essence of thing (D ing-an-sich), had it consigned to the noumenon evocative of the paradoxical nature of human knowing: it regulates the boundaries according to which any notion of the infinite, the universal or the absolute can be reflexively thematized, or, thus strategically said, problematized.

For Kant, the noumenon (or thing-in-itself) opens up for Man an expansive totality, provides him a secured place of transcendence that is made available to human strategic purposes by bringing it over (transœendence as both possibility and a potential) to a kind of venture. Hence, the thing-in-itself is a result of our venturing into the open waters and the vast landscape of Being at the same time that it conducts us to perform, most of all, our mastery and understanding of the world. It is therefore a precondition of being shut within a bounded world. For Kant, the noumenon is the limit of pure reason; this limit secures the path of knowing in that knowing is secured against the desire to arrogate the infinity or the absolute, an appropriation that destroys the precondition - the very condition of possibility - of transcendence. In short, of human freedom.

Meanwhile, Heidegger's project of a destructive retrieval of the fundamental question of Being would identify metaphysics with forgetfulness (of Being), or the problematic of the obscuration of being in Western metaphysics, with the goal of interrogating metaphysics from within. Having cast the Kantian 'limit' against the systematic eclipsing of the question of Being by way of interrogating presenœ to which Western metaphysics has rendered Being subservient, Heidegger unmasked a kind of metaphysics of presence, certainly a philosophical standpoint that grounds Being as an 'object' of the act of representation. There the task of representation is a twofold handiwork: 1) whatever 'is' stands as a being 'set up' by the knowing agent, and; 2) the 


\section{6}

\section{THE 'TURN' TO TIME}

transparency of 'what is' becomes the sole dimension of Being that lends itself to pure presence. For Heidegger, this metaphysical objectification of Being is deeply problematic, which obtains its most ominous expression in the age of technology or the world picture ( $\mathrm{G}$ estell). Being is not an object standing before thought, or, as being made 'in thought'. Being is rather the representation of absence, or the concealment of the unconcealed. Curiously enough, it is of the nature of Being to escape the rigidity of concepts, of ideational and theoretical grounding. In short, of representation. Even so, it is through a certain notion of boundedness (which gives form to being) that Being unfolds itself.

This configuration of Being, as it is taken up in Heidegger's interrogation of the presuppositions of metaphysics, rather brings to light its aesthetic dimension. An aestheticism that gives primacy to the eventuating trace of Being rather than of Being itself, an eventuation of Being in isolation from itself. Incidentally, in Kant, the thematic of isolation occupies a central place: the noumenon operates in isolation from its pure negativity in order to allow for an event, a happening, a humanly and mortal happening borne rather of fundamental limitation, and therewith, the work of transcendence. The noumenon could thus be posited here as a therapeutic device where a certain immanentism, a self-sufficient inhibiting dis-inhibitor- and also a disinheriting inheritance - is brought into play, a safety net made possible by grasping the paradoxical nature of a fundamental limitation that alone precedes any work of transcendence (a limitation that gives rise to freedom itself) against the globalizing propensity of representation. To this end, aesthetic reflection exemplifies a strategic schema of interrogation.

It is also said of aesthetic contemplation that it isolates Being from its own work of unconcealment such that our projective understanding of It is not totally helpless before Its own unconcealing work. We have drawn this configuration of Being from several predominant themes in Heidegger-Kant dialogue concerning their deconstructive projects. In Kant, the negativity of the thing-in-itself lends Being into our awareness of the boundedness of transcendence, whereas in Heideggger, Its aesthetic dimension allows a 'foil' in our understanding of its determination such that 'understanding' (V erstehen) itself is received into the double bind of presence and absence. Both themes will render the task of representation aesthetically problematic. For the question of being to properly inspire a destructive retrieval of the presupposition of metaphysics (in Heidegger's work), Being has to be understood as standing apart from all forms of representation (either in pure or practical reason). This is not to say, however, that Being has to be left untouched such as by any attempt at interrogating metaphysics whose ultimate presupposition rests in the enigmatic concept of Being. Rather it is supposed to be intrinsically problematic in that a better, more strategic concern of understanding the historical implications of its paradox, how centuries of trying to unpick and re-thread the fibers that were made to constitute our understanding of Being have actually influenced the way we have been constituting ourselves, our environment and the whole symbolic network of the so-called human traffic with Nature. This kind of relating to Being has 
also dramatically shaped our methodic way of interrogating its enigma, from postructuralism to deconstruction, and to the contemporary rehabilitation of passive nihilism prompted by Nietzsche and Heidegger, ${ }^{1}$ with a peculiar pragmatic inclination suggestive of the radical insinuations of a Deweyan concept of democracy. ${ }^{2}$ All these contemporary attempts are in a way renegotiations or reoccupations of the problematic which preoccupied Heidegger's Seinsfrage or the question of Being, which as this essay tried to set out on, was a throwback of the Kantian divide between pure and practical reason. On hindsight, Kant sought to bridge the gap in the sense of transcending the limitations of pure and practical reason by venturing into the aesthetic, or how our judgments are actually creative negotiations with all forms of human and natural limitations. In this way, human judgments, whether borne of pure or practical negotiations with reality, are inherently arguable, disputable, and contestable, hence, open to change or to larger human strategic ends.

Kant's turn to a critical interrogation of the bases of our judgments is a step forward, which Heidegger would take up and problematize anew. Nevertheless, what Heidegger saw in problematizing the aesthetic (taking cues from Kant) is not for the epistemological and moral divide to be finally bridged by a unifying intuitive element typical of aesthetic contemplation, but rather (breaking with Kant) for our limited judgments to come to terms with reality. Later, Heidegger would associate aesthetic contemplation with a philosophical therapy, an avowal of forgetfulness, that is, forgetfulness of the absurd at the same time taking a positive opportunity from the fact that forgetting may also be an act of remembering. Or, rather a therapeutic un-remembering if only to expose the inherent inauthenticity of human understanding enough to accord it a limit according to which knowledge can transcend its inauthentic condition, certainly a paradox that gives existence its due, ${ }^{3}$ a topic earlier suggested by Heidegger's celebrated problematization of the arguments of Being and Time that tells much of his so-called Kehre, or simply put, the turn of emphasis from 'Being' to 'Time'.

This turning point in Heidegger's philosophy is also heightened by his realization of the problematic of representation and of subjectivity which over the course of human progress has led us away from a fundamental understanding of the temporal basis of our judgments. For Heidegger, the receding of Time is the reason behind the ever fateful oblivion of Being itself; Time as an important and critical awareness of the horizon of understanding Reality (couched in the term Being as Reality's most fundamental and ultimate condition of possibility, therefore, its founding limit) in terms of the continuing tradition of the metaphysics of subjectivity, which, as Heidegger, in his later

1 Gianni Vattimo, Nihilism and Emancipation, trans. by William McCu (New York: Columbia University Press, 2004).

2 Richard Rorty, Objectivity, Relativism, and Truth: Philosophical Papers (New York: Cambridge University Press, 1991).

${ }^{3}$ Martin Heidegger, "On the Essence of Truth," in Basic W ritings of Martin H eidegger, ed. by D avid F. Krell (London: Routledge, 1978), 132. 


\section{8}

THE 'TURN' TO TIME

essay particularly in $0 \mathrm{n}$ The Q uestion Concerning Technology, acutely detected, is radically oriented toward the "ability-to-be-be master." 4 When the temporal horizon of understanding is minimally, if not completely hurled into the back seat of human knowledge, Being runs the risk of becoming purely the handiwork of a commanding subjectivity in the fashion of a Man who has occupied the place vacated by God. ${ }^{5}$ A fundamental understanding of time therefore situates human knowledge within the most intelligible horizon of its possibility, namely, human knowledge is always the result of our negotiation with reality, a reality that keeps changing with the time, which rather proves the contingency or the finitude upon which our understanding of Being is, for the most part, dependent.

Needless to say, the inability of pure and practical reason to bridge the expansive gap subsisting between Being and beings is played out in the imaginative creativity of aesthetic contemplation, an imaginative apprehension of the opaqueness of being - its double bind. Its indeterminateness corresponds to the tenacious instability of Being that shuttles back and forth unto itself as much as it endorses a fundamental understanding of the blind spot immanent to human knowledge, which rather allows us to see things in their true paradoxical light.

\section{The Nature of Being: Heidegger's Turn}

"The horizon of philosophy bears witness to how, with regard to the horizon essentially necessary for them and to the assurance of that horizon, all ontological interpretations are more like a groping about than a methodical or univocal questioning." 6

We begin here with a task, that is, the task of discovering a key, among others, to understanding a type of discursive predicament that had badgered a thinker as the author of this canonical text in Western philosophy. Among the various problematic threads that are sown up into this rather difficult corpus, Heidegger's turn (Kehre) is one of the most discursively appealing.

We can hazard an observation here that the key to understanding Heidegger's turn (Kehre) is the problematization of the unfinished project of Being and Time within the context of a promised continuation of his work on fundamental ontology vis-à-vis a re-assessment of the whole project overlaid by subjectivist themes. We are referring to the delayed 'third part' of Being and Time. The reason for the delay was not technical, rather one of a fundamental hesitation in the face of Being. He clarified that the task of pursuing the fundamental question of Being would have to rely, at least, on a metaphysics of subjectivity that he, however, sought to avoid. But if Seinsfrage were to be properly informed by a non-representational way of interrogation, Heidegger

\footnotetext{
${ }^{4}$ Ibid., 79.

${ }^{5}$ Ibid., 100.

${ }^{6}$ Martin Heidegger, The Basic Problems of Phenomenology, trans. by Albert Hofstadter (Bloomington: Indiana University Press, 1982), 322.
} 
would have to abandon the metaphysics of subjectivity. This is the context in which we can speak of the 'turn'. Heidegger is precise at one point: the question of Being and Time is predicated upon an early, more originary experience of time which is the real forgetfulness of being. The condition of possibility of laying the groundwork for the fundamental question of being is the forgetfulness of being, that is, how it comes to pass that subjectivity has become forgetful of the temporal horizon of being? Y et even an account of this 'more originary experience' is bound to the destiny of incompletion, the fate of miscarriage, which attests to the abyss called Being.

Nevertheless, what is called the originary is implicated here: there can be no originary experience of time in a strictly temporal sense. The becoming of time that we experience is the being-ness of this becoming, the nominating (in the language of deconstruction) of this becoming to a categorical or representational form. What happens to time during this process is what presumably happens during understanding itself. A combined process of absolute nomination and negotiation with reality, a naming of being to beingness guided by one's fundamental awareness of the historical, thus, human temporal dimension which necessarily limits the act of transcendence or exercise of human will. If there is absolute reality out there, this whole process is doomed to fail from the beginning. There is simply no tolerance to negotiation in an absolute world. But granting that there is not, the process becomes open to creative and re-creative acts of negotiating with the limitations that are borne of human finitude and the contingency around which reality sets in. We cannot choose the kind of limitations we would bear to live through. Rather we are thrown into somewhere where it is up to us to nominate a place, a properly habitable dwelling for us, where we learn to replenish our "world on the basis of latest needs and wants" 7 which need be necessarily forgetful of the absurd wholeness of being-thrown. But, oblivious only to some extent. A destructive retrieval of the history of the oblivion of Being, which Heidegger set out to do in Being and Time, sets this record straight. Something of Being does not flee from us nor nothing of It. To put it more philosophically, it is not the whole of Being that is the fundamental issue, rather the fundamental forgetfulness of thrown-ness that, if snatched back to its rightful contingent place in the imaginative beginning of human time (that is, the destructive retrieval of Time) in our own phenomenological experience of it (as a process or duration), will properly bring knowledge to its humble yet enabling place, namely, that no knowledge is absolute. Even so, awareness does not redeem us from oblivion. It will always be a continuing experimentation where the dangers of regressing into the subjectivist claim to permanence and absoluteness are always dramatically present, ever playful with the finitude that can be easily tempted into the notion of the ultimate, partly due to its helpless adherence to a form of hope, a hope that conceals deeply rooted ambition of greatness, of grandeur, of omniscience.

\footnotetext{
${ }^{7}$ Heidegger, Basic W ritings of M artin H eidegger, 132.
} 


\section{0}

\section{THE 'TURN' TO TIME}

Heidegger's promise to publish the 'third part' remained unfulfilled. In the course of his utter dissatisfaction with the text, he burned it. In his later works, we can see how deeply this turn has affected Heidegger as a theoretician of being. Abandoning the metaphysics of subjectivity, Heidegger sought to experience, instead, the spontaneity of Being, a reversal of his vocation as a thinker into an ecstatic participant (especially his work in Poetry, L anguage, and Thought). The role of imagination in these ecstatic ruminations is obviously marked, compared with the speculative bearing of fundamental ontology in the early works.

Within the architectonic of Being and Time, the fundamental horizon of metaphysics endorses an understanding of being as a way to reflect upon the human subject as an "autonomous, completely self-transparent subjectivity" or "the rationality of a sovereign subject." 8 In contrast, the so-called philosophical 'turn' questions the direction to which the task of fundamental ontology is leading, that is, a complete self-understanding of being. The horizon of subjectivity is something that Heidegger in his succeeding works would refuse the analytic of being to fall back on. The radical shift in his later ontological project must be understood in the light of the fundamental limitation of being to bring the task of fundamental ontology to a decisive conclusion. This limitation is rather the forgetfulness of being that metaphysics had brought itself to believe it had achieved, within the horizon of intelligibility.

Prefiguring the radical shift in his thought, Heidegger undertook a critical self-assessment regarding the 'delayed' publication of the 'third part' of Being and Time. The horizon of intelligibility is a temporal horizon, the transcendental horizon of D asein. Nevertheless, the temporal interpretation of being betrays a fundamental predicament: "the projection of being upon the horizon of its understandability... stands continually being exposed to the danger of being reversed." 9 D rawing from Kant and Husserl, Heidegger's notion of temporality in Being and Time is centrally pre-occupied with necessary and universal conditions (the a priori structures) of the possibility of being made intelligible by the projecting power of the mind. However, this notion of temporality reveals a deficient analytic of being. The secret presupposition of the essential and unquestionable status of the a priories in the structural determination of being commands subtle yet absolute authority over $\mathrm{D}$ asein. In this sense, transcendental subjectivity systematically conceals an ahistorical notion of the a priori. This timeless projection of the a priori is prone to the scheme of reifying being "and proceeding as though being allowed itself to be embraced in a project of subjectivity." 10

The radical reformulation of the question of the meaning of being would bring Heidegger into the interrogation of the limitations of traditional metaphysics, such as his interrogation of the definition of 'the thing':

\footnotetext{
${ }^{8}$ Jean G rondin, Sources of H ermenuetics (Albany: University of New York Press, 1995), 68.

${ }^{9}$ Heidegger, The Basic Problems of P henomenology, 323.

${ }^{10} \mathrm{G}$ rondin, op. cit., 68.
} 
The unpretentious thing evades thought most stubbornly. Or can it be that this self-refusal of the mere thing, this self-contained independence, belongs precisely to the nature of thing? Must not this strange and uncommunicative feature of the nature of the thing become intimately familiar to thought that tries to think the thing? If so, then we should not force our way to its thingly character. ${ }^{11}$

Heidegger's refusal to subsume the sovereign status of the thing to the subjective will of the agent reveals his break with traditional metaphysics. The turn (Kehre) in Heidegger's thinking, therefore, marked a transition of preoccupation from the question of $\mathrm{D}$ asein to the question of being itself. The latter is concerned with the question of temporality of being which fosters an essential contemplation of the finite mode of being-in-the-world. The turn sought to leave subjectivity behind along with the task of submitting being to the ultimate project of comprehension. Jean Grondin summarizes the development of Heidegger's thought that reveals the anticipation of the turn, silently foreclosing the project of fundamental ontology in Being and Time:

Being is that in which (or rather, by which since we have nothing to do with it) we are projected into this world and to which we could never claim to possess the key. This thinking of Geworfenheit is certainly already present in Being and Time, and in this respect, the work was already on the way to leaving the horizon of intelligibility of subjectivity behind. This same thinking will eventually present an obstacle to a project which is rigorously conceptual (or, if we may risk the term, strictly rational), a project which seeks to attain being from the horizon of Dasein. For Dasein proves to be too finite and too historically situated to obtain a perspective on being which would enable it to derive sub specie aeternitatis the transcendental structure of its most fundamental being. ${ }^{12}$

The notion of thrownness ( $\mathrm{G}$ eworfenheit) reveals the ontological timbre of the 'turn': since D asein is thrown into the world, being could not be made to appear as a 'ground' or a 'thing' at our disposal. Certainly, this is one of the consequences of finitude through which Dasein operates in and through the realm of Being. In this light, radicalizing finitude (which a refusal of

${ }^{11}$ Martin Heidegger, Poetry, L anguage, Thought, trans. by Albert Hofstadter (N ew York: Harper and Row, 1971), 31-32.

${ }^{12} \mathrm{G}$ rondin, op. cit., 68-69. 


\section{THE 'TURN' TO TIME}

metaphysical totality suggests) aims to shake the complacency that impels the continuing history of ontology by problematizing the antical framework of understanding. While it is true that the very same emphasis on finitude is seriously challenged by the limitations that subtend to Dasein's thrownness, the tum in Heidegger's thought would make use of finitude to give credence to the priority of being over D asein. In order to take the full measure of the tum, Heidegger's task "will be directed toward liberating man from the dominion of ontical reification, so as to expose him to his essential insignificance in the face of being." 13 In other words, the radicalizing of finitude entails acceptance of the paradox of being. In a similar vein, Heidegger explicitly connects the understanding of truth to the openness of being to errancy-

In conformity with its openness and its relatedness to being as a whole, every mode of comportment has its mode of erring. Error extends from the most ordinary wasting of time, making a mistake, and miscalculating, to going astray and venturing too far in one's essential attitudes and decisions. However, what is ordinarily and even according to the technique of philosophy recognized as error, incorrectness of judgments and falsity of knowledge, is only one mode of erring, and moreover, the most superficial one. The errancy in which any given segment of historical humanity must proceed for its course to be errant is essentially connected with the openness of Dasein. ${ }^{14}$

Due to the ontical restraint bearing down upon being-the particularity of the point of view around which uncovering is organized-being is made open to errancy whose most representative form is becoming oblivious to the finitude of knowing. Heidegger states: "The concealing of the concealed being as a whole holds sway in that disclosure of specific being, which, as forgottenness of concealment, becomes errancy." 15 The forgottenness of the concealedness of being, which is ontologically linked with the failure to recognize the particularity around which uncovering takes place, is typical of metaphysics. Negatively, metaphysics is associated with a 'sleight of hand', a conscious schema to forget being through disguising the ontical in the splendid garb of ontological presence that obscures the question of the meaning of being. In other words, the 'turn' executes a strategy of ontological destruction that avoids the totalizing and contriving schema of the metaphysical reduction of being into the horizon of subjectivity. Nevertheless, the avoidance of totalization will always remain a self-conscious act.

\footnotetext{
${ }^{13}$ Ibid, 73.

${ }^{14}$ Martin Heidegger, BasicWritings, ed. by D avid F. Krell (London: Routledge, 1993),

${ }^{15}$ Ilid, 133
} 133-134. 


\section{The Aesthetic Leap into Being through the Reformulation of Time}

"Concealedness exists inasmuch as the realm in which they belong together is the abyss of Being." 16

In Part IV of Kant and the Problem of Metaphysics, Heidegger sought to retrieve the background against which one can "appropriate the results of Being and Time, and in the richest sense prepare the way for it." 17 This background, strongly implied in the Critique of Pure Reason, is the retrieval of the basic problem of metaphysics that pre-occupied the First Critique but was systematically hindered by 'long concealed possibilities' Kant ignored in laying the groundwork of metaphysics. Heidegger outlines his strategy:

Thus the fundamental intention of the present interpretation of the Critique of Pure Reason was to make visible in this way the decisive content of this work and thereby to bring out what Kant 'had to say.'18

Efforts such as "to place within the unsaid" and "force it into speech" characterize the direction of the Heideggerian retrieval, to entrust interpretation 'to the concealed inner passion of a work.'19 Yet Heidegger would emphasize also the deficiency of the Kantian founding retrieval in the same Kant-discourse:

Kant's laying of the ground for metaphysics leads to the transcendental power of imagination. This is the root of stems, sensibility and understanding. As such, it makes possible the original unity of ontological synthesis. This root, however, is rooted in original time. The original ground which becomes manifest in the ground-laying is time. 20

In the Basic Problems of Phenomenology, which along with Kant-discourse forms a link to Being and Time, Heidegger states his view on the limitation of Kant's understanding of temporality. Kant's critical ontology of the universal relation of time to subjectivity did not successfully avoid the pervasive use of temporality that shaped the ancient $G$ reeks' inclination to view the L ogos as pure presence. Kant himself interpreted being as absolute position. But, for Heidegger:

${ }^{16}$ Heidegger, Poetry, L anguage, Thought, 97.

${ }^{17}$ Frank Schalow, The Renewal of H eidegger-Kant D ialogue: A ction, Thought, and Responsibility (Albany: State University of New York Press, 1992), 168.

18 Martin Heidegger, Kant and the Problem of Metaphysics, trans. by Richard Taft (Bloomington: Indiana University Press, 1990), 137.

${ }^{19}$ Ibid., 138.

${ }^{20}$ Ibid. 


\section{THE 'TURN' TO TIME}

Position is to be interpreted here again as we interpreted perception: not the positing and not the posited and also not positedness; instead, being is that which is already understood in positing as the letting-stand of something on its own self; it is what is already understood in positing as a specific intentional comportment according to its directional sense: the thing's being-stood-upon-its-ownself with all its predicates, the self-determined presence of a thing. ${ }^{21}$

The basic limitation of Kant rests on his consigning the realm of possibility to the function of 'cognizing something a priori'. Heidegger interpolates this proposition by proceeding first to underwrite its discursive intent- to make known in the light of 'whatness' and 'howness' the temporal determination of the a priori. For Heidegger, all ontological propositions are temporal propositions. ${ }^{22}$ Only in the sense of their being temporal propositions that ontological proposition 'can and must be a priori propositions.' 23 Kant would rather limit his transcendentalism to the possible, which is "nothing less than this: the grounding of the inner possibility of ontology is brought about as an unveiling of transcendence, i.e., \{an unveiling\} of the subjectivity of the human subject." 24 The purpose of the Kant-discourse is to expose the inadequacy of the project of the Critique of Pure Reason in the light of the proper transcendental problematic evoked in the laying of the ground for metaphysics. Kant's philosophical anthropology followed the empirical direction of placing the subject at the helm of ontic determination. Heidegger's stance is more critical: for him the limitation of Kant "now makes of the demand for an adequate, i.e., a philosophical anthropology, for the purpose of laying the groundwork for metaphysics, even more pressing." 25

In section 21 of the Basic Problems of Phenomenology, subtitled The Kantian interpretation of being and the problematic of Temporality, Heidegger achieves the following assessments:

Only through Temporal interpretation does Kant's assertion that being equals position, so striking at first, acquire a realizable sense, which the Neo-Kantians have fundamentally misunderstood. Kant obviously did not intend his proposition that being equals position to mean that the subject would first create the thing and bring it into being out of its own self; instead, he surely understood the equivalence of being and position in the

${ }^{21}$ Heidegger, The Basic Problems of P henomenology, 316-317.

${ }^{22}$ Ibid., 324.

${ }^{23}$ Ibid.

${ }^{24}$ Heidegger, Kant and the Problem of M etaphysics, 140.

${ }^{25}$ Ibid., 140-141. 
way we have interpreted him, without having the possibility of bringing this understanding into explicit conceptual form, because he lacked the means for original interpretation. ${ }^{26}$

Heidegger saw Kant's unspoken presupposition of the ground-laying for metaphysics in the latter's analysis of the "essence of knowledge and finitude, which for Heidegger, has 'attained the character of a decisive problem'." 27 Heidegger's task is to increase the stakes of the project of retrieval initiated by Kant, to rescue him from the Scholastic paradigm to which Kant's concept of finitude is secretly bound. Placing Kant's formulations within the unsaid and forcing them into speech, Heidegger reveals the pestering difficulty Kant endured out of an intellectual handicap borne of his Scholasticism, a paradigm, in fact a pervasive worldview which methodically situates human finitude within the alienatory nature of divine presence as its ens creatum-

And even if the impossible were possible, even if a Beingcreated of man could be rationally proven, then by means of the characterization of man as an ens creatum, we would only prove once more the fact of his finitude, would not exhibit its essence, and would determine this essence to be the basic constitution of the Being of man. ${ }^{28}$

Kant's problematization of time is an important keynote of Heidegger's turn which would guide his own reinterpretation of time as constitutive of an imaginative play-force that gives the understanding of the notion of temporality a more originary sense. In the succeeding section, we will try to present how Heidegger reformulates the Kantian problematic. We will also try to connect Heidegger's retrieval of the Kantian notion of time to his later turn and how it helped shaped the 'silence' that marks and around which Heidegger's later pursuits developed, working on the shadow of the unfinished project of fundamental ontology.

\section{The Decisive Reformulation of Time}

"Hence time is the primary horizon of transcendental science, of ontology, or in short, it is the transcendental horizon .... Ontology is at bottom Temporal science; therefore philosophy, understood in the proper sense and not taken

\footnotetext{
${ }^{26}$ Heidegger, The Basic Problems of P henomenology, 317.

${ }^{27}$ Heidegger, Kant and the Problem of M etaphysics, 149.

${ }^{28}$ Ibid., 150.
} 


\section{THE 'TURN' TO TIME}

straightaway in a Kantian sense, is transcendental philosophy-but not conversely." 29

Kant's reformulation of time concerning subjectivity, according to Heidegger, has initiated the questioning of the limits of traditional metaphysics and ontology, although Kant hesitated to push his work much farther, beyond the $\mathrm{G}$ reek concept of the $\mathrm{L}$ ogos widely regarded then as the universal ground of understanding. The self's pre-predicative constitution as allegedly given rise to by the Logos equally gives rise to the idea of the subject as presence. As presence, the subject is said to possess of the reputed transparency of the light that shines on its own being - the L ogos. It is presence in the sense that the $\mathrm{L}$ ogos is made transparent but still indefinable on account of its transpredicative constitution, its abysmal richness. Paradoxically, the L ogos reveal themselves through the medium of the subject in the projective appearance of its inarticulate nature. With Kant's reformulation, the problematic of how the subject comes into being from out of the operation of the L ogos has become more compelling. Kant believes that time as pure self-affection forms the essential structure of subjectivity; the constitution of time as the structure of subjectivity is pure intuition.

Although Kant's introduction of temporality gives new light on the problematic of the emergence of the subject, his paradoxical resolution of the inadequacy of traditional metaphysics into the noumena leaves the project of critical philosophy unfulfilled. For Kant, the resolution of this crisis rests on faith. Kant resolved the unthought into the noumena whose appearance of unattainability ironically echoes the play of logocentric presencing. Correspondingly, Kant understood time as the pure sequence of nows. This sequence of nows is in no way time in its originality. "On the contrary, the transcendental power of imagination allows time (as sequence of nows) to spring forth, and as this letting-spring forth, it is therefore original time." 30 Through the power of imagination, the unity of subject and object is constituted in time. This unity is pure intuition itself. Kant stressed that pure intuition had to be a kind of experience accessible to our finitude. Taking this cue, Heidegger would pursue the project of fundamental ontology through the decentering of metaphysics in a new light:

Hence from the beginning . . . the power of imagination is never simply dependent upon the presence of being. It is dependent in this way to such a small degree that precisely its pre-forming of the pure schema of Substance, that is, persistence over time, for example, first brings into view in general something like constant presence. In turn, it is first and foremost only in the horizon of such constant presence that this or any present presence of an object as such can show itself.

\footnotetext{
${ }^{29}$ Heidegger, The Basic Problems of Phenomenology, 323-324.
}

${ }^{30}$ Heidegger, Kant and the Problem of Metaphysics, 120. 


\section{RIVAS 77}

Hence, in the transcendental Schematism, the essence of the power of imagination-to be able to intuit without the present presence-is grasped in a way that is fundamentally more original. ${ }^{31}$

Another difference between Heidegger and Kant is approached here in the light of the notion of absence. For Kant, 'absence' is denied of its ontologicity in the sense that it has no being of some sort (the noumena). For Heidegger, this absence is the other play-space of reason which enters into reciprocity with the parallel process of "gathering forth in advance what is to be unified." 32 Heidegger instead proposes an elaboration of the question of being that radicalizes the impossibility of posing the nothing or the notion of absence. 'Nothing' speaks of the transcendent constitution of the Real, or in $\mathrm{K}$ ant, the $\mathrm{D}$ ing-an-sich. It underlies the fundamental fact of human finitude, condemned to the gap between intuition and concept, which 'proves necessary the act of thinking'. Thinking is the kind of tension produced by the overlapping negations of the real and symbolic. It is a forgetting of the nonobjectivity of the Real; the forgetting of the gap to which being (the human agent) is condemned between infinite and finite, the universal and particular, real and symbolic. This is contrasted to the act of forgetting that denies the temporal origin of transcendence. It is therefore an act of forgetting that does not forget itself, that is to say, forgetting is a strategic negotiation with the Real, a self-conscious act of nominating being to being-ness, which to that self-same consciousness, is rather a reflexive creation, an imaginative yet therapeutic invention of the Real where there is not.

Even supposing, the question of being in the framework of nothing or absence, according to Heidegger, is needlessly imbued with 'the commonly cited ground rule of all thinking: the proposition that contradiction is to be avoided or universal logic itself.' 33 Incidentally, in the history of ontology, the history of beings, the forgetting of the temporal is determinable through the analysis of how, specifically, 'the term being, in the guise of the copula, is, has lost all import as a spur to inquiry. ${ }^{34}$ Metaphysics has reached its absurd completion through assigning a privileged beginning to thought in the form of is. It would have meant the end of philosophy or the 'thinking of being' based on the arbitrary promulgation of identity that violently displaces the dynamic (or temporal) character of being into the metaphysical rule of absolute totality. However, this absurd completion would pave the way for the advent of scientific-technological thinking that renews the oblivious project of metaphysics in relation to the question of being in a more reductive direction where Being is placed under the tutelage of exact methods and procedures.

${ }^{31}$ Martin Heidegger, N ietzsche, vol. 1, trans. by Joan Stambaugh, Frank A. Capuzzi and D avid Farrell Krell (New York: Harper and Row Publishers, 1987), 278-283.

${ }^{32}$ Schalow, op. cit., 196.

${ }^{33}$ Heidegger, Basic W ritings, 97.

${ }^{34}$ Schalow, op. cit., 206. 


\section{THE 'TURN' TO TIME}

With the metaphysical mastery of the oblivion of the temporal character of the reciprocity between being and time, the problem of transcendence comes about. Being is thought through transcendence. Transcendence consists in the "precursory grasp or advance orientation to the object." 35 According to Heidegger, this is the reason transcendence remains inescapably rooted in finitude. He also adds that obliviousness to the temporal reciprocity (between thought and object) amounts to the privileging of 'thought' as the instigator of the unity of categories; yet a kind of 'thought' whose predicative power is emptied of intuition or of the pure self-affection of the I think, the imagination to which both Kant and Heidegger assign the common root of understanding and sensibility.

Against this background, Heidegger resolves to see imagination as enacting an ontological synthesis that unites receptivity and spontaneity of thinking. Receptivity prefigures the innovative expanse of a space where the anticipation of the manifold of sense transpires. This space gives priority to aesthetics over logic. In this sense, Heidegger is reviving the issue of limits that led Kant to explore the neglected dimension of human finitude. He transposes the ethical focus of Kant's problematic speculation of the contradiction between transcendence and limitation into the unexplored dimension of finitude. Kant's later ethical leap overlaps the original tack assigned to the play-space of imagination. He summoned forth an extra-ordinary imaginative act of thought that remains tied to judgment. In contrast, Heidegger shifts his attention to the prepredicative level of transcendental experience in undoing the privileging of the subject as presence and instigator of unity.

\section{The Problem of Transcendence}

With the metaphysical mastery of the oblivion of the temporal character of the reciprocity between being and time, the problem of transcendence comes about. Being is thought through transcendence. Transcendence consists in the "precursory grasp or advance orientation to the object." 36 According to Heidegger, this is the reason transcendence remains inescapably rooted in finitude. He also adds that the obliviousness of the temporal reciprocity (between thought and object) amounts to the privileging of 'thought' as the instigator of the unity of categories; yet a kind of 'thought' whose predicative power is emptied of intuition or of the pure self-affection of the I think, the imagination to which both Kant and Heidegger assign the common root of understanding and sensibility.

Against this background, Heidegger resolves to see imagination as enacting an ontological synthesis that unites receptivity and spontaneity of thinking. Receptivity prefigures the innovative expanse of a space where the anticipation of the manifold of sense transpires. This space gives priority to aesthetics over logic. In this sense, Heidegger is reviving the issue of limits

\footnotetext{
${ }^{35}$ Ibid., 175.

${ }^{36}$ Ibid.
} 
that led Kant to explore the neglected dimension of human finitude. $\mathrm{He}$ transposes the ethical focus of the Kant's problematic speculation of the contradiction between transcendence and limitation into the unexplored dimension of finitude. Kant's later ethical leap overlaps the original tack assigned to the play-space of imagination. He summoned forth an extraordinary imaginative act of thought that remains tied to judgment. In contrast, Heidegger shifts his attention to the prepredicative level of transcendental experience in undoing the privileging of the subject as presence and instigator of unity.

\section{Conclusion}

Heidegger's reformulation of temporality influenced the 'turn' as the problematization of the paradoxical finality of the task of fundamental ontology, its destiny in failure, its miscarriage. The influence that Kant had on Heidegger, meanwhile, is obvious - it showed the latter the path to a more original projective understanding of being. Kant's critical ontology became a powerful impetus for Heidegger's project (in Being and Time) such that it provided a clearing whereupon the problem of subjectivity could be reinstated in a clearer light. The key is the understanding of time as the primordial horizon of subjectivity which Kant consigned to pure intuition that is bound to ever-greater limits which are in a sense self-imposed. For Heidegger, the enigma of the D ing-an-sich is not the handiwork of the pre-predicative reality of the unattainable absolute, rather of the abyss, or call it an aporia called Being. This will imply that the subject is not in itself totally incapable, also intimating a promise of self-mastery and objectification (a la Hegel). Nevertheless, the question of being is not for the subject to resolve but for Being itself to perpetuate. The primordiality of time is the key to understanding this. Being is such that our fundamental relation to it constitutes obliviousness. Forgetfulness underscores the fact of our being thrown, that is, into Time as the ontological structure of the world. Thrown in time: we are lost in time, exsisting in time in the sense of seeing 'becoming everywhere,'37 in which 'being' is overlaid by impermanency, indeterminacy and change. But for $\mathrm{D}$ asein to be and be-come it must somehow constitute itself as self-forgetful, that is, forgetful of thrownness, of becoming, of the helpless absurdity of things. (Or in relation to Kant: the forgetfulness of being is the isolation of the noumenon from itself, thus, revealed as a regulatory principle).

Underscoring the turn, Heidegger would take issue with the metaphysics of intelligibility to which his previous works were systematically attached. Within the context of the turn, the role of imagination is crucial. The shift into the aesthetic dimension of being provides a key to a more original form of ecstatic participation in spontaneity. It is clear in Heidegger that the forgetfulness of being-the essential constitution of Dasein's experience of

\footnotetext{
${ }^{37}$ Friedrich Nietzsche, The U ses and A buses of $\mathrm{H}$ istory, trans. and ed. by Julius K raft (N ew York: Liberal Arts Press, 1957), 6.
} 


\section{0}

THE 'TURN' TO TIME

Time- precedes the question of being. Time precedes Being. In this reversal of ontology, the notion of time is identified with a freer, unbounding play of Being participating in the spontaneity of forgetfulness. It is so to speak a double forgetfulness, an authentic, ecstatic way of existence. Heidegger would also speak of this as becoming genuinely at home with Being. O ne forgets the forgetfulness of being, forgets time as tragically thrownness, to get hold, 'at least', of being (and hence, of essential subjectivity) yet need not claim to posses of its imperious, and therefore, overbearing potency. Above all these, paradoxically enough, because the possibility of Being in human temporal space rests on its forgetfulness, we subsequently forget that it is not Time that we are actually forgetful of but Being itself. Worst, we forget that Being is a result of our compromise with the yet to be known or that has yet to become penetrable by language. Language as the very strategic possibility of Being, its proper dwelling, its homely ground upon which it can thrive as forgetfulness. Lastly, if we look at how language is very much tied up to a larger social symbolic network, we will not miss the point that language is a tool for human compromises, negotiations, strategic advances, and to cap it all, a weapon for survival. A kind of surviving that necessarily forgets where there is nothing to remember, where there is much to anticipate rather in the open space of time ahead of us.

Institute of Social H istory, Polytechnic U niversity of the Philippines, Philippines

\section{References Cited}

Grondin, Jean, Sources of H ermenuetics (Albany: University of New York Press, 1995).

Heidegger, Martin, Being and Time, trans. by John Macquarrie and Edward Robinson (Oxford: Basil Blackwell, 1967). Poetry, L anguage, Thought, trans. by Albert Hofstadter (New Y ork: Harper and Row, 1971). "On the Essence of Truth," in Basic W ritings of Martin H eidegger, ed. by D avid F. Krell (London: Routledge, 1978). , The Basic Problems of Phenomenology, trans. by Albert Hofstadter (Bloomington: Indiana University Press, 1982). N ietzsche, vol. 1, trans. by Joan Stambaugh, Frank A. Capuzzi and D avid Farrell Krell (New York: Harper and Row Publishers, 1978). Kant and the Problem of Metaphysics, trans. by Richard Taft (Bloomington: Indiana University Press, 1990). , Basic W ritings, ed. by D avid F. Krell (London: Routledge, 1993).

Kant, Immanuel, Critique of Pure Reason, in Kant Selections, ed. by Lewis White Beck (New Y ork: Macmillan, 1988).

Nietzsche, Friedrich, The $\mathrm{U}$ ses and A buses of $\mathrm{H}$ istory, trans. and ed. by Julius Kraft (New Y ork: Liberal Arts Press, 1957).

Rorty, Richard, 0 bjectivity, Relativism, and Truth: Philosophical Papers (New York: Cambridge University Press, 1991). 
Sherover, Charles, "Heidegger's Use of Kant in Being and Time," in Kant and Phenonomenology, ed. by Joseph Kockelmanns (Washington: University Press of America, 1986).

Schalow, Frank, The Renewal of $\mathrm{H}$ eidegger-Kant D ialogue: A ction, Thought, and Responsibility (Albany: State University of New Y ork Press, 1992).

Vattimo, Gianni, N ihilism and E mancipation, ed. by Santiago Zabala, trans. by William $\mathrm{McCu}$ (New York: Columbia University Press, 2004). 